5

5

6

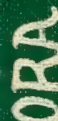

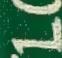

H.

니

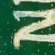

$=$ 1 


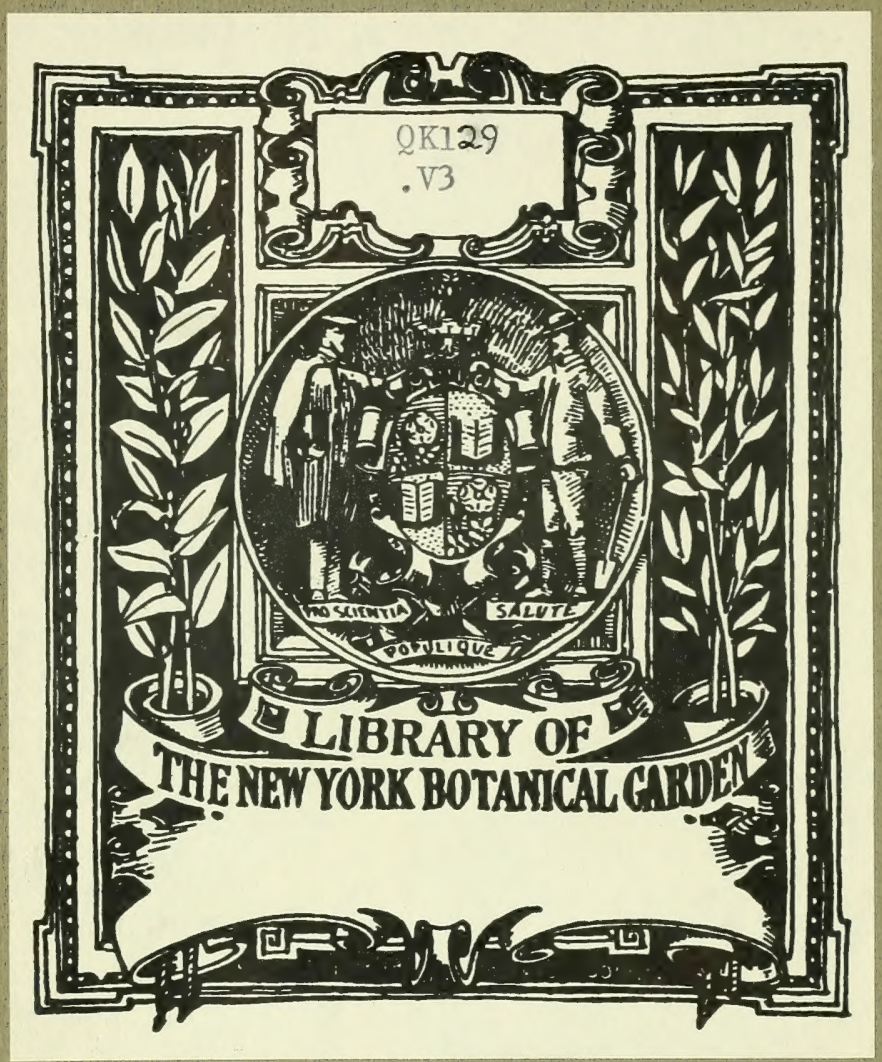




\section{Garden and Forest.}

T.IBRPARY

\section{The June Flora of a Long Island Swamp}

$\mathrm{O}$

NLY those that have watched the gradual growth and development of a field of wild flowers can realize the amount of enjoyment that can be derived from the daily inspection of a few acres of marshy meadow-land. Every visit reveals new beauties, and usually new plants, that, no matter how carefully every foot of ground has been gone over before, have escaped the rigid scrutiny of a plant-lover's eye. The swamp that has been the source of much pleasure and entertainment to me for three successive summers is situated at the head of a small pond, where for a very short part of the winter the salt water penetrates, but it is, however, essentially a fresh-water swamp. The spring that fills it starts in a low meadow, a short distance off, and grows rapidly into a little brook that spreads itself into a broad expanse of bog, widening here and there into broader pools that harbor many a delightful waterweed, till it ends half a mile away in deeper and clear water in the pond. It is divided into three portions: a sloping peaty meadow, that gradually becomes too soft and wet to cross; a long boggy stretch, principally filled with rushes; and further on, an almost impenetrable thicket composed of a variety of shrubs and small trees, such as Andromeda, Leucothoë, Rhododendron, Clethra, Viburnum, Myrica and many others, most conspicuous among which are the Swamp Maples, with their pale leaves, and some very Japanesque-looking Tupelos, Nyssa sylvatica. Between the meadow and the road is a long row of fine aged White Willow's, which in beauty rival the Elms for which East Hampton is justly famed.

The swamp and meadow were first visited this year on the $17^{\text {th }}$ of June, and, besides Daisies, Buttercups and white and pink Clovers along the upper dry portion, it was filled all the way down to the bog with Blue-eyed Grass, Sisyrinchium Bermudiana. The plants were so thick everywhere that it seemed scarcely possible to step without crushing a hundred, and so tiny that their color did not affect the general tone of the meadow as did the masses of Meadow Soft Grass, Holcus lanatus, the spikes of which were not yet in bloom. A more beautiful sight can hardly be imagined. Whether the salt air helps the color of Holcus or not, the manual does not tell, but surely it is nowhere as brilliant a silvery pink-purple as it is here, and, perhaps, for the same reason it is known to the farmers as "Red Top." Down nearer the bog, Pogonia ophioglossoides filled the grass with its little pink buds, with here and there a few in bloom. Splendid Yellow Thistles, Cnicus horridulus, were scattered around, and, notwithstanding their repelling name, are very handsome, decorative things to look at, but at the same time very awe-inspiring to the plant-collector. They are scarcely more than two feet high, usually lower, with a rosette of long, very prickly leaves, spreading flat on the ground; most beautiful leaves, 
Q/129

.$V_{3}$ 
too, with a broad reddish or reddish-purple midvein and margin, each prickle purple, with a yellowish tip. The flowers are pale, creamy-yellow, with splendid royal purple involucres.

Creeping through the grass everywhere were the little white flowers and slender shoots of the Running Swamp Blackberry, Rubus hispidus, and the long branches of the Cranberry; but not a flower on the latter was to be seen, and nowhere in the swamp was a shrub in bloom. Here and there, all over the meadow, were fine clumps of the Flowering Fern, its rusty-brown fertile panicles towering above the tallest grass top and the shorter, paler green tufts of the Sensitive Fern. A slight stretch of the imagination will include in the meadow a waste strip of ground on the edge of the road, where the Lupin runs riot over the sand in long-stemmed, long-spiked masses of deep-blue Pea flowers. The contrast of the flowers against the yellow sand was very fine. The pod is also handsome, clothed with a long, fine down. Another prominent blue flower, but this one growing in the wettest part of the bog, is the little Blue Flag, Iris prismatica, a slender, graceful thing that at that time was abundant in every wet place.

The next day more Pogonias were in bloom, and here and there through the grass the Cranberry-buds were showing. The little Sundrops were more and more numerous, and rivaled the Buttercups in the brilliancy of their yellow. The species is that described in Gray's Manual as Enothera fruticosa, var. humifusa, and is there accredited as growing only in Suffolk County, Long Island, and it is certainly very common here. It is, as its name implies, a low, spreading plant; its stems are somewhat woody, reddish, and, as well as the leaves and capsules, very puberulent, but the flowers are not by any means always small; some of them, when fully expanded, are over one and a quarter inches broad.

Careful search in a dry corner revealed the curious, delicate, little green Orchid, Twayblade, Liparis Lœselii. Never found in great numbers, it is a pleasant surprise to come upon a little colony hidden among the grasses. It has a stiff, perky, independent way of growing, with two broad glossy leaves and a delicate spike of thread-like flowers. Often, too, the previous year's dry capsule clings to the old bulb, which persists for quite a while.

A couple of days later the first Wild Rose, Rosa lucida, was seen; the tall, somewhat flesh-colored stems of Aletris farinosa were noted among the grass, and off among the rushes faint white gleams told of the Woolgrass, Eriophorum cyperinum, that was beginning to bloom.

Two more days, and on the $22 \mathrm{~d}$, the Pogonia-flowers by the hundred extended as far as the eye could reach, growing sometimes out of the water. There were so many of them that their perfume, a curious mixture of violets and vanilla, pervaded the atmosphere. They are charming, dainty things, and have a contented way of growing up out of the Sphagnum without any visible means of support in the bulb line, like their near relatives, the Twayblade. Another Orchid, Calopogon pulchellus, the Pogonia's almost invariable companion, made its first appearance that day; it is taller, larger, bright magenta-purple, and very gaudy and self-assertive. There was only one of them in bloom, but little, round, greenish buds here and there at the top of slender flexuous stems told of many more to come. 

The Arrow-wood, Viburnum dentatum, suddenly appeared in full bloom on the outskirts of the meadow, great flat cymes of snowy flowers that, unfortunately, were covered with that all-devouring pest in this region, the rose-bug.

Sunday, the $23 \mathrm{~d}$, was a dull day, and nothing new was noticed except that one Swamp Honeysuckle, Rhododendron viscosum, had ventured to put out a few blossoms. Everything else was doing its best to atone for the gray skies, and a marvelous sight they were, the rusty bog, with its fringes of bright green Ferns, dotted here and there with yellow Sundrops, the delicate purple grass in full bloom making a kind of iridescent veil over all the meadow, and above the great silvery mass of the old Willows against the leaden sky. A spell of wet weather followed, and when it was dry enough to penetrate into the meadow most of the Sisyrinchium had disappeared, and in the place of the little blue flowers were the many hundreds of small, hard, round, green capsules. The bloom of the Arrow-wood was also destroyed; many of the Red Clovers, Trifolium pratense, had turned brown; the Iris was fast shriveling, and the Wool-grass was very wet and bedraggled. The only things that had not suffered were the Pogonias, which, if possible, were larger, finer and more numerous than before. The Roses had come out, many of them, too, but mostly little dwarf things, only a few inches high in the meadow, where they were kept low by being cut down with the grass. Among the shrubbery the Black Alder, Ilex verticillata, showed its tiny round buds. They were scarcely larger than a common pin-head, but ready to bloom on the first sunny day. Both kinds are there-the staminate, with small sessile clusters ; the fertile, with solitary little buds in the axils of the leaves. Here and there were the flexuous spikes of a Habenaria only six inches or so above the ground. The Star-grass, Aletris farinosa, was in bloom, an attractive plant, often found in sandy soil. It has a spreading rosette-like cluster of flat lanceolate leaves at the base on the ground and a solitary, tall, stiff stem with a wand of white flowers of the size and aspect of those of the Lily-of-the-valley at the top. The corolla is all crisped and wrinkled, and looks as if made of fine white paper crêpe, and just appearing at the top of the bell are six little orange-colored stamens. The yellow Loosestrife, Lysimachia stricta, made its first appearance that day, and the little sticky leaves of the Round-leaved Sundew, Drosera rotundifolia, were noticed in quantities riding on the top of the peat-moss.

A long week's rain ended the month, and on the last day the fog was too thick to see across the swamp, where the water stood deep in every depression, and the peat was as soft as a wet sponge, quite impassable, even to a weedhunter. Once clear skies again, the July flowers will appear all the faster and be fresher and more brilliant for the good soaking they received in June.

East Hampton, L. I. Anna Murray Vail. 

QK 129. New York Botanical Garden Library

Vail, Anna Murray/The June flora of gen

i A f lora of a

\section{HLET BINDERS}

This is No. 1526

in stock in the following sizes

THICKNESS HIGH WIDE THICKNESS

$381 / 2$ inch 152912 inches 10 inches $1 / 2$ inch

is 153012 inch $91 / 8 \quad \frac{4}{4} \quad 1 / 24$

\begin{tabular}{l|llllll}
4 & 1932 & 13 & 4 & 10 & 4 & 4 \\
4 & 1933 & 14 & 4 & 11 & 4 & 4 \\
4 & 1934 & 16 & 4 & 12 & 4 & 4
\end{tabular}

pr sizes made to order.

MANUFACTURED BY

RARY BUREAU

ON OF SPERRY RAND CORPORATION

rary Supplies of all Kinds 
